\title{
Effect of Different Wine-Making Techniques on the Composition and Quality of Pinotage Wine. I. Low-Temperature Skin Contact Prior to Fermentation
}

\author{
J. Marais* \\ ARC Infruitec-Nietvoorbij, Private Bag X5026, 7599 Stellenbosch, South Africa \\ Submitted for publication: February 2003 \\ Accepted for publication: July 2003 \\ Key words: Pinotage, Low-temperature skin contact, esters, phenolic compounds, wine quality
}

\begin{abstract}
The effect of low-temperature skin contact prior to fermentation $\left(1,2\right.$ and 4 days at $10^{\circ} \mathrm{C}$ and $15^{\circ} \mathrm{C}$, respectively) on Pinotage wine composition and quality was investigated over four seasons (1999 to 2002). The extraction of total polyphenois (total flavonoids, total tannins and total anthocyanins) was followed during skin contact and fermentation. Wines were analysed for total polyphenols and esters, and sensorially evaluated for Pinotage cultivar character (berry/plum) intensity and overall wine quality. Polyphenol extraction rates differed greatly between the skin contact treatments. Polyphenol concentrations in the final wines increased slightly with an increase in prefermentation skin contact tune. Acetate ester concentrations generally decreased with an increase in prefermentation skin contact time. Wine quality differed significantly between some treatments and the most typical and highest quality Pinotage wines were produced by prefermentation skin contact for 4 days at $10^{\circ} \mathrm{C}$ and the lowest by the control and skin contact for 4 days at $15^{\circ} \mathrm{C}$.
\end{abstract}

Vitis viniferaL. cv. Pinotage was bred in South Africa in 1924 as a cross between Pinot noir and Cinsaut noir (Hermitage). Wines of this cultivar display distinctive fruity characters, described as plum-, cherry-, red berry-, black berry- and banana-like. During the last ten years a national co-ordinated initiative, supported by viticultural and oenological technology development, was launched to market this cultivar world-wide. As a result of its South African uniqueness and distinctive character, Pinotage is now increasingly in demand locally and internationally. Research on Pinotage is at present focused on the development of technology that will optimise grape and wine composition and quality.

Phenolic compounds, such as flavonoids, tannins and anthocyanins are extracted from grape skins during crushing, skin contact, fermentation and pressing, and play a major role in the composition and quality of red wines. Of equal importance is the extraction of cultivar-impact aroma components from the skins. Naturally, conditions during skin contact are of the utmost importance. Increased colour characteristics as a result of low-temperature maceration $\left(10^{\circ} \mathrm{C}\right)$ in the beginning of fermentation were reported by Gómez-Plaza et al. (2000). Recently, prefermentation low-temperature maceration (cold soak) received attention for adding complexity to red wines. Heatherbell et al. (1997) reported increases in phenol concentrations, anthocyanin concentrations and colour intensity, as well as increases in blackberry, woody/tobacco and spicy aroma intensities in Pinot noir wines as a result of cold soak at $4^{\circ} \mathrm{C}$. Similarly, increased colour and blackcurrant flavour in Shiraz wines were obtained with the application of cold soak, followed by fermentation at $30^{\circ} \mathrm{C}$ and postfermentation maceration (Reynolds, et al., 2001). It is reasoned that the absence of alcohol during prefermentation skin contact allows the formation of higher molecular weight phenolic compounds which enhance colour stability (Timberlake \& Bridle, 1976). McMahon et al. (1999) demonstrated increases in Cabemet Sauvignongrape glycoside levels and colour as a result of cold soak treatments. It is well known that hydrolysis of these precursors may result in an increase in intensity and complexity of wine aroma and an enhancement of wine quality (Sefton, 1998).

Not much research on the effect of low-temperature prefermentation maceration on wine composition and quality has been done to date. Furthermore, knowledge about the composition of specifically Pinotage grapes and wines is lacking. The purpose of this study was therefore to determine the effect of low-temperature skin contact prior to fermentation on Pinotage wine composition and quality.

\section{MATERIALS AND METHODS \\ Grapes}

Pinotage grapes from the same vineyard on the Nietvoorbij farm (Stellenbosch region) were used during four seasons (1999 to 2002). In all cases grapes were harvested at approximately $23^{\circ} \mathrm{B}$ to $24^{\circ} \mathrm{B}$. Grape treatments and wine-making

Grapes were divided into two equal, representative lots (each 27 cases $=540 \mathrm{~kg}$ ) and stored overnight at $10^{\circ} \mathrm{C}$ and $15^{\circ} \mathrm{C}$, respectively. After storage, each lot was divided into three equal, representative parts ( 9 cases each) for three different prefermentation treatments. The three treatments were: 1 day, 2 days and 4 days skin contact, respectively. The grapes were destemmed, crushed and $80 \mathrm{mg} / \mathrm{L}$ total $\mathrm{SO}_{2}$ added. Skin contact was conducted at the same temperatures as during storage, i.e. $10^{\circ} \mathrm{C}$ and $15^{\circ} \mathrm{C}$, respectively. After skin contact the juice/skin mixtures were transferred to a $25^{\circ} \mathrm{C}$ room, inoculated with Saccharomyces cerevisiae strain WE 14 (Anchor Bio-Technologies) and fermented dry. Fermentation temperatures were monitored daily. During skin contact and fermentation, caps were punched down three times daily

*E-mail address: johannm@infruit.agric.za

Acknowledgements: Technical contributions by Ewarda Swart, Francois October, Adele Louw and Christopher Paulse, as well as financial support by the South African Wine Industry (Winetech), the Pinotage Association and the Agricultural Research Council are appreciated. 
until completion. The control grapes (representative of the rest of the experiment) were crushed directly after harvesting, destemmed and had no skin contact prior to fermentation. The whole experiment was done in triplicate. Wine-making was completed according to standard Nietvoorbij procedures for smallscale, red wine production. No malolactic fermentation and wood contact were conducted. Samples for analyses were collected daily over the whole period from the beginning of skin contact to the end of fermentation.

\section{Polyphenols}

Total flavonoids, total tannins and total anthocyanins were extracted from the samples of the juice/skin mixtures and wines, and analysed spectrophotometrically according to the method of Di Stefano et al. (1989), as adapted by Nicolini \& Valenti (2001).

\section{Esters}

Esters were extracted from the wines by Freon 11 and the extracts analysed gas chromatographically (Marais, 1986). The esters analysed were iso-butyl acetate, iso-amyl acetate, hexyl acetate, ethyl butyrate, ethyl hexanoate, ethyl octanoate and ethyl decanoate.

\section{Wine quality}

Wines were sensorially evaluated six months after production for berry/plum intensity and overall wine quality by a panel of six experienced judges. A line method was used, i.e. evaluating the berry/plum intensity or overall wine quality by making a mark on an unstructured, straight $10 \mathrm{~cm}$ line. The left-hand and right-hand ends of the line were indicated respectively by the terms, "undetectable" and "prominent" for intensity, and by "unacceptable" and "excellent" for quality. Wines were also ranked according to the above-mentioned wine quality characteristics. The control was ranked separately against the $10^{\circ} \mathrm{C}$ treatments, as well as against the $15^{\circ} \mathrm{C}$ treatments.

\section{Statistical analyses}

Statistical differences between treatments were determined by applying standard analysis of variance methods to the data. Least significant differences (LSD) were calculated to facilitate comparison between treatment means (Snedecor \& Cochran, 1980).

\section{RESULTS AND DISCUSSION}

\section{General}

Fermentation temperatures peaked at $28^{\circ} \mathrm{C}$ and the peak times varied according to skin contact time prior to fermentation. This temperature was adequate, since a fermentation temperature of between $28^{\circ} \mathrm{C}$ and $32^{\circ} \mathrm{C}$ is beneficial for the production of high quality Pinotage wines (Marais \& Malan, 1999). This is in accordance with results on Pinot noir and Shiraz, where more intense colour and higher wine qualities were obtained at higher fermentation temperatures $\left(30^{\circ} \mathrm{C}\right)(\mathrm{Gao}$ et al, 1997; Girard et al, 1997; Reynolds et al, 2001).

\section{Polyphenols}

Extraction rates of total flavonoids, tannins and anthocyanins differed among treatments according to skin contact time and a peak, followed by a slight decrease (or plateau), was reached at approximately similar concentration levels (Fig. 1). The 1999 results are representative of trends obtained over the whole experimental period. The results are also in agreement with those of other researchers who found that anthocyanins and total phenolics reached maximum levels early during fermentation, followed by decreases in anthocyanin levels, while those of phenolics tended to remain stable or decrease very slowly (Mayén et al, 1995; Watson et al, 1995; Mazza et al, 1999). After fermentation, monomeric anthocyanin concentrations gradually decreased, while those of polymeric anthocyanins increased (Gao et al, 1997).

When the total polyphenol concentrations in the bottled wines are considered, slight increases in their concentrations with an increase in skin contact time at $10^{\circ} \mathrm{C}$ were observed (Fig. 2). However, at $15^{\circ} \mathrm{C}$ slight decreases were observed between 2 and 4 days treatments. Extended skin contact may result in wines with lower anthocyanin concentrations, due to degradation or precipitation of these compounds (Watson et al, 1995). The highest values were observed for the 4 days $/ 10^{\circ} \mathrm{C}$ and 2 days $/ 15^{\circ} \mathrm{C}$ treatments. Total polyphenols were not determined in the bottled wines of the 1999 season.

\section{Esters}

Fermentation bouquet volatiles, such as esters and higher alcohols, are important in the quality of all wines. Young Pinotage
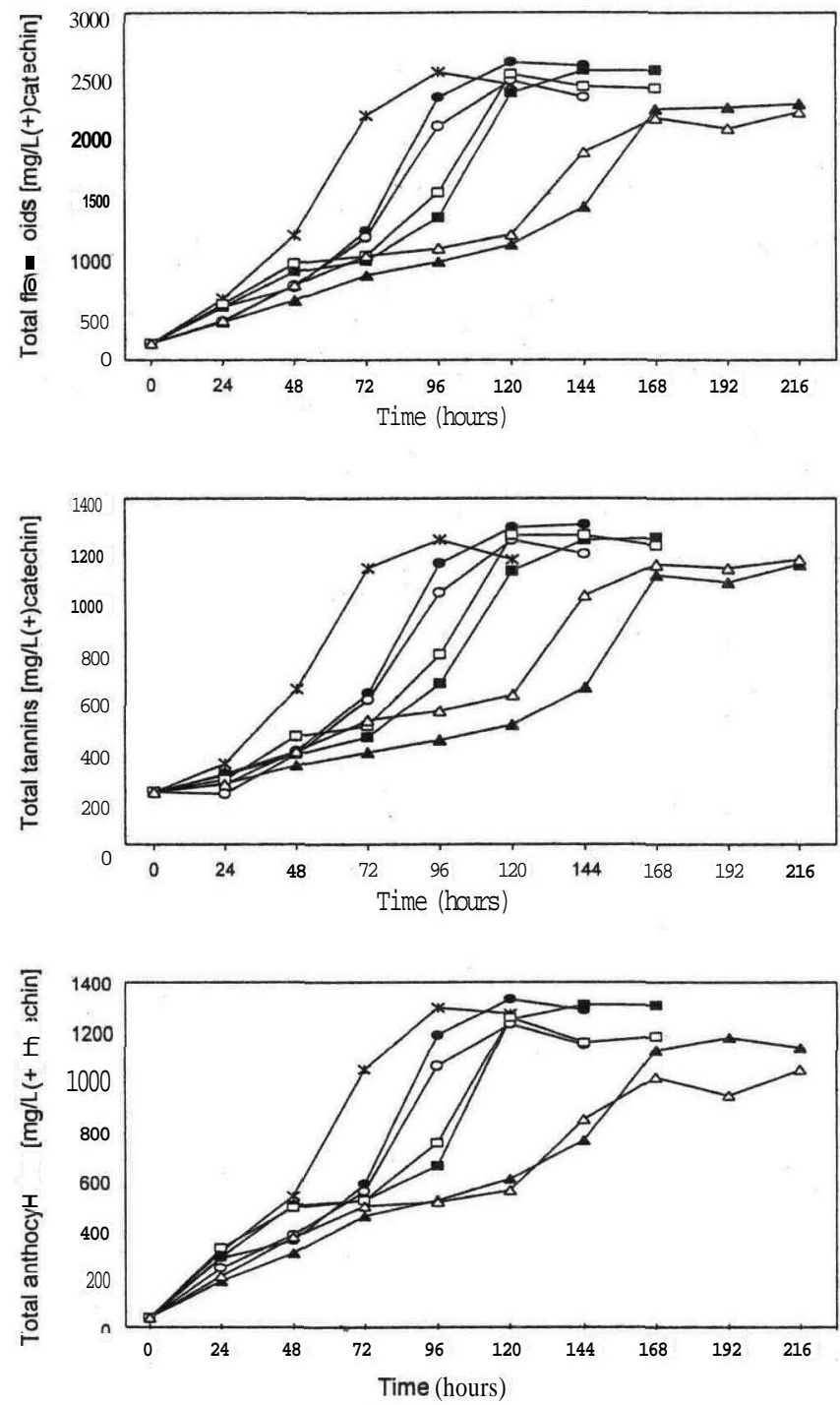

FIGURE 1

Effect of low-temperature skin contact (SC) prior to fermentation on total flavonoid, tannin and anthocyanin extraction in Pinotage juice/wine (1999 season).

$*$ = Control; $=10^{\circ} \mathrm{C} 1$ Day SC; $»=10^{\circ} \mathrm{C} 2$ Days SC; $\mathrm{A}=10^{\circ} \mathrm{C} 4$ Days SC; $\mathrm{o}=15^{\circ} \mathrm{C} 1$ Day SC; $\mathrm{a}=15^{\circ} \mathrm{C} 2$ Days SC; $\mathrm{A}=15^{\circ} \mathrm{C} 4$ Days SC. 


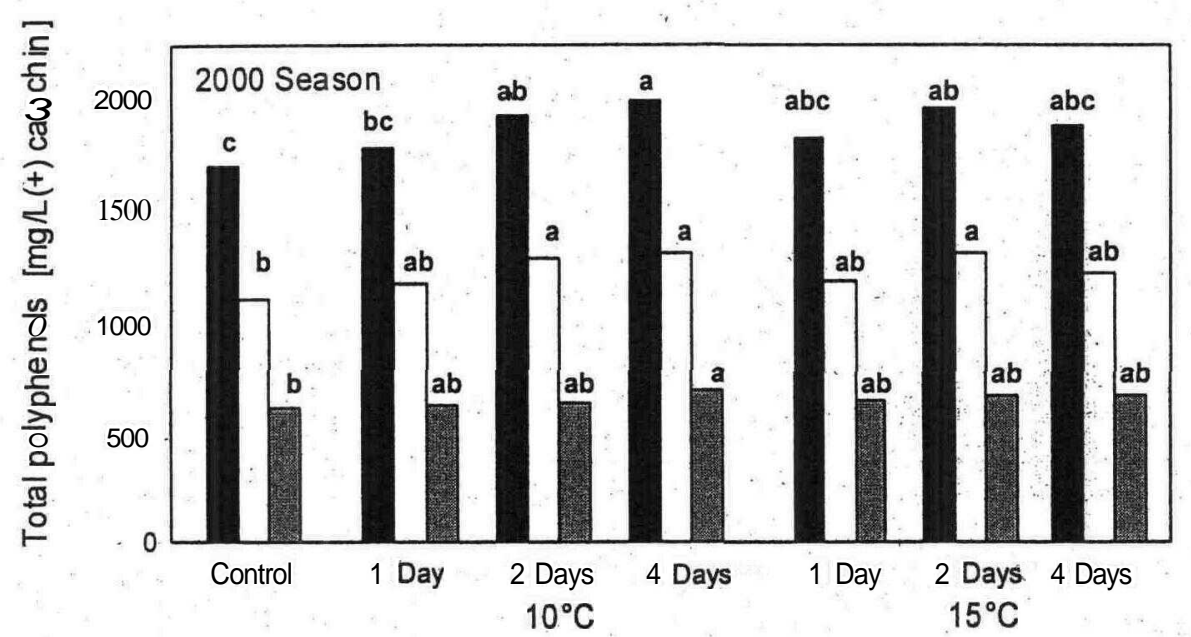

Skin contact temperature and duration

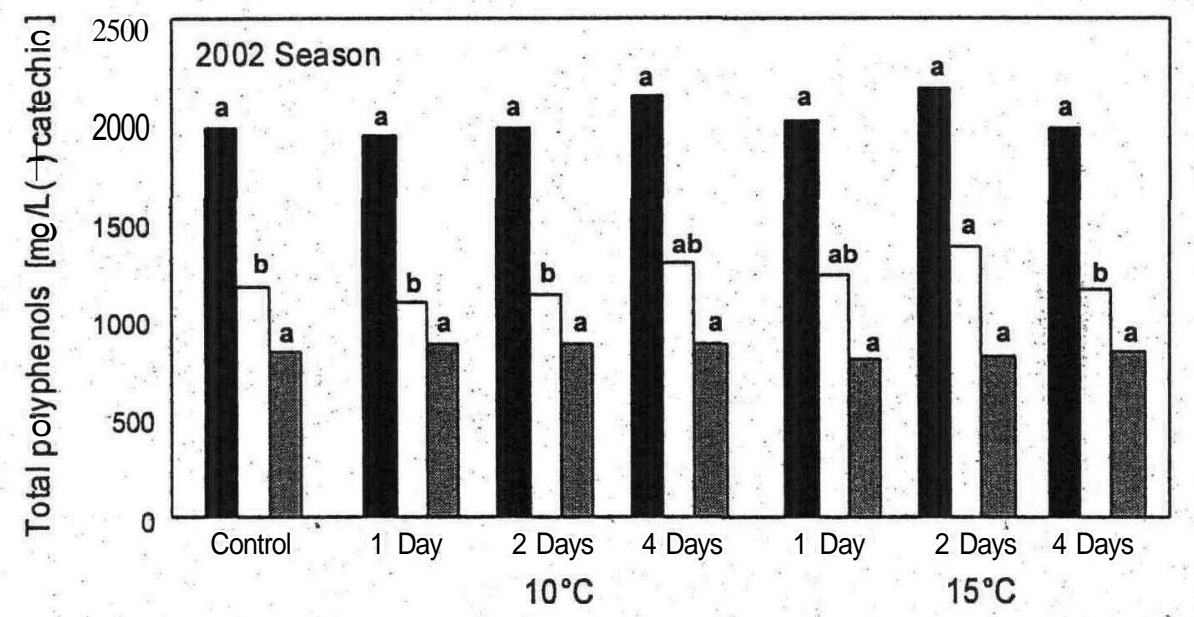

Skin contact temperature and duration

FIGURE 2

Effect of low-temperature skin contact $\left(10^{\circ} \mathrm{C}\right.$ and $\left.15^{\circ} \mathrm{C}\right)$ for 1,2 and 4 days prior to fermentation on total polyphenol concentrations in Pinotage wines. Treatments (each phenol group viewed separately) designated by the same letter do not differ significantly $(\mathrm{p}<0.05)$. - = Total flavonoids; $\mathrm{D}=$ Total tannins; $\bullet=$ Total anthocyanins.

wines are characterised by relatively high ester concentrations, especially iso-amyl acetate (Van Wyk et al., 1979). When in moderate concentrations, this component is responsible for a pleasant banana-like aroma, but in too high concentrations it can exhibit a negative "nail-polish/duco"-like character. Although the bananalike character is important, it was mostly masked by the berry/plum-like aroma, which is preferred in full-bodied Pinotage wines. Acetate ester concentrations generally decreased with an increase in skin contact time, especially at $15^{\circ} \mathrm{C}$ (Fig. 3). The highest levels were obtained for the control and the $10^{\circ} \mathrm{C}$ ( 1 and 2 days) skin contact treatments. Similar tendencies were obtained* for ethyl esters (data not shown).

Differences in the measured component levels among seasons are naturally ascribed to differences in grape composition at harvest, caused by differences in climatic conditions and grape maturity.
It can be reasoned that concentrations of unknown, cultivartypical, grape-derived components might have followed similar trends to those of the polyphenols or acetate esters. For example, grape-derived aroma, liberated from sugar-bound glycosides (McMahon et al., 1999), might have played a role in this regard. Preliminary indications are that beta-damascenone and betaionone may be important impact aroma components of Pinotage (Waldner \& Marais, 2002).

\section{Wine quality}

The following tendencies were observed: generally, the 4 days/ $10^{\circ} \mathrm{C}$ treatment yielded the highest quality wines, and the control and 4 days $/ 15^{\circ} \mathrm{C}$ treatments, the lowest quality wines (Fig. 4). During the 2000 and 2002 seasons the quality of the 4 days $/ 10^{\circ} \mathrm{C}$ wines was statistically higher than that of the control. This observation applies to the typical berry/plum character intensity, as 

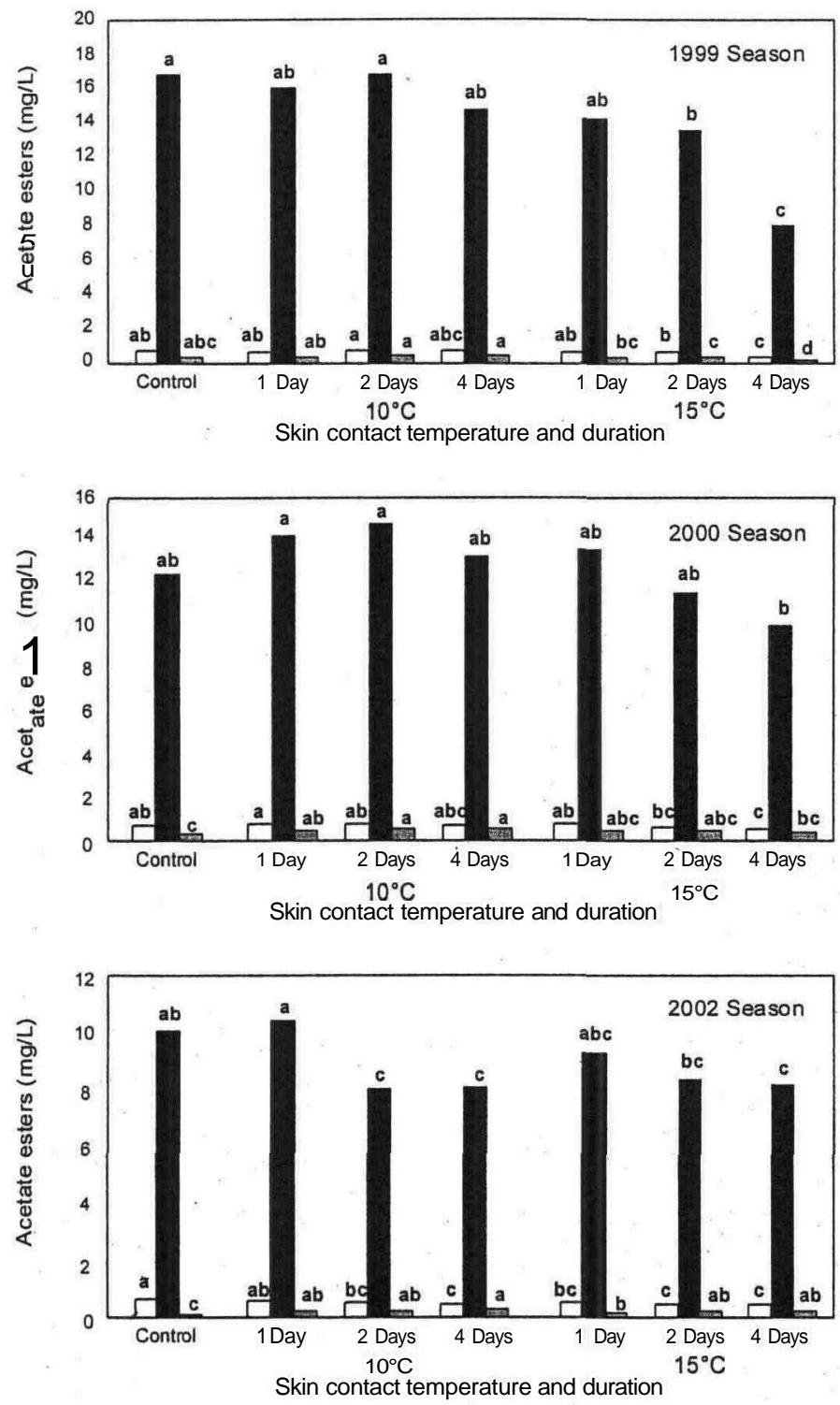

FIGURE 3

Effect of low-temperature skin contact $\left(10^{\circ} \mathrm{C}\right.$ and $\left.15^{\circ} \mathrm{C}\right)$ for 1,2 and 4 days prior to fermentation on acetate ester concentrations in Pinotage wines. Treatments (each aroma component viewed separately) designated by the same letter do not differ significantly $(\mathrm{p}<0.05)$.

$\mathrm{D}=$ iso-Butyl acetate; $\bullet$ = iso-Amyl acetate; $\bullet=$ Hexyl acetate.

well as to overall wine quality. The reason for the higher quality of the 4 days $/ 10^{\circ} \mathrm{C}$ wines is probably due to the longer skin contact, which resulted in a more complete extraction of cultivar-typical aroma components. Furthermore, it appears that an increase in skin contact temperature - by as little as $5^{\circ} \mathrm{C}$ prior to fermentation - may affect wine quality negatively. This is in agreement with findings that low-temperature cold soak $\left(4^{\circ} \mathrm{C}\right)$ of Pinot noir grapes resulted in darker, less bitter wines than cold soak at a higher temperature $\left(10^{\circ} \mathrm{C}\right)$ (Heatherbell et al., 1997).

Sensory ranking of the wines confirmed individual evaluation results to a great extent (Table 1). Generally, the 2 days $/ 10^{\circ} \mathrm{C}$ and 4 days $/ 10^{\circ} \mathrm{C}$ treatments yielded the highest quality wines. When
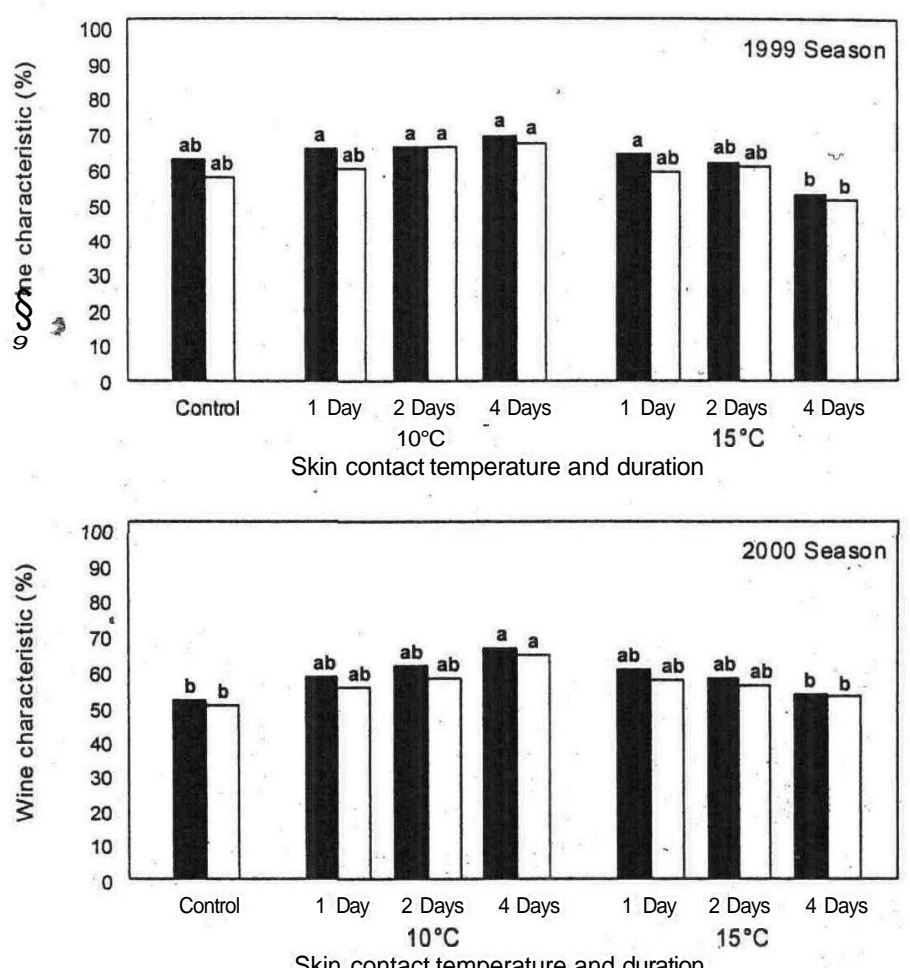

Skin contact temperature and duration

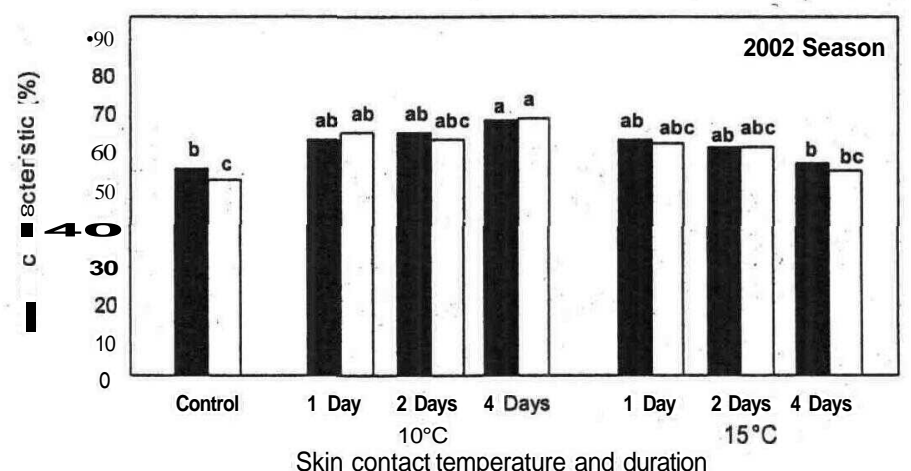

FIGURE 4

Effect of low-temperature skin contact $\left(10^{\circ} \mathrm{C}\right.$ and $\left.15^{\circ} \mathrm{C}\right)$ for 1,2 and 4 days prior to fermentation on Pinotage wine quality. Treatments (each wine characteristic viewed separately) designated by the same letter do not differ significantly $(\mathrm{p}<0.05)$. - = Berry/plum intensity; $\mathrm{D}=$ Overall wine quality.

the control was compared to the $15^{\circ} \mathrm{C}$ treatments only, the 2 and 4 days treatments again tended to produce the highest quality wines. This is with respect to the 4 days $/ 15^{\circ} \mathrm{C}$ treatment, contrary to what was found when wines were considered individually (Fig. 4).

During the 2001 season no statistical differences between treatments were observed (data not shown). The reason(s) for this phenomenon is (are) not clear. However, when the wine quality data were averaged over all four seasons (1999 to 2002), tendencies and in some cases statistical differences between some treatments (Fig. 5) were in agreement with those observed during individual seasons (Fig. 4). 


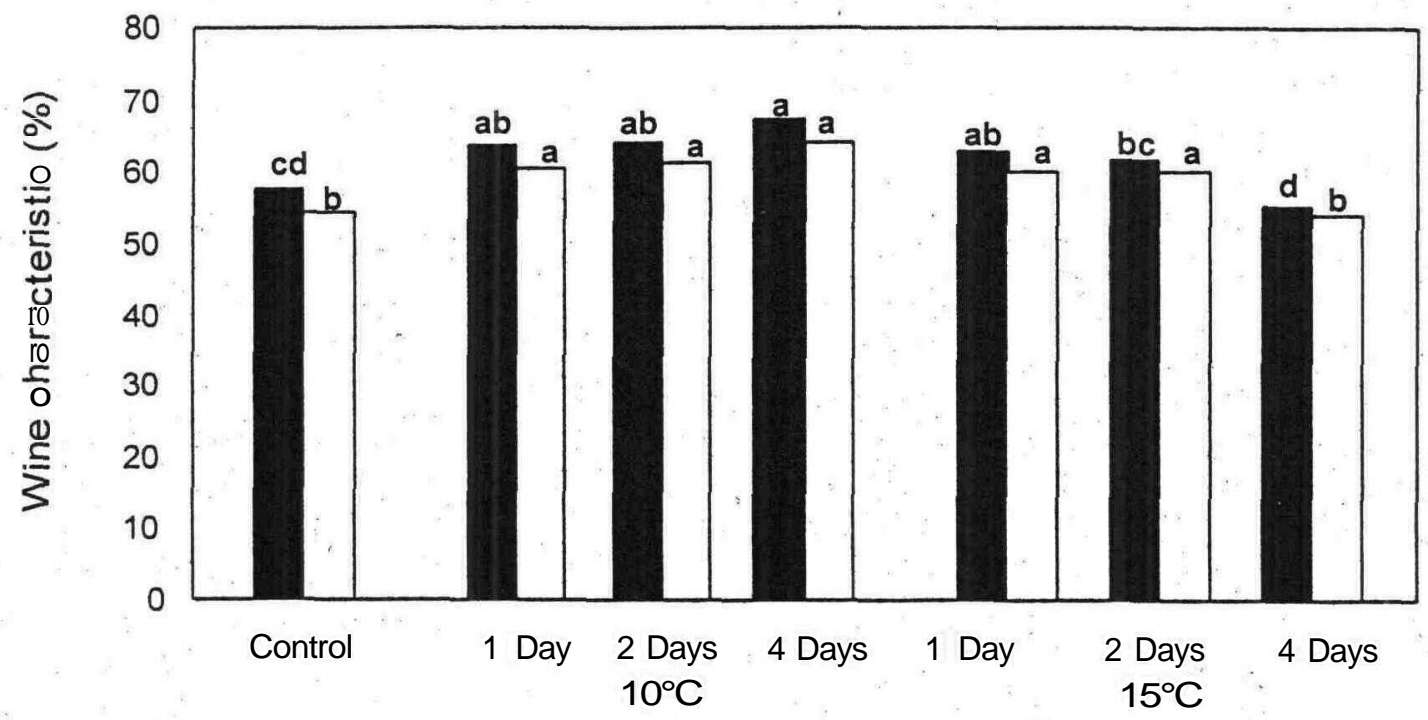

Skin contact temperature and duration

FIGURE 5

Effect of low-temperature skin contact $\left(10^{\circ} \mathrm{C}\right.$ and $\left.15^{\circ} \mathrm{C}\right)$ for 1,2 and 4 days prior to fermentation on Pinotage wine quality (1999, 2000,2001 and 2002 seasons combined). Treatments (each wine characteristic viewed separately) designated by the same letter do not differ significantly $(\mathrm{p}<0.05)$. $\bullet$ = Berry/plum intensity; $\mathrm{D}=$ Overall wine quality.

TABLE 1

Ranking of Pinotage wine quality according to different skin contact treatments prior to fermentation.

\begin{tabular}{|c|c|c|c|c|c|c|c|c|}
\hline \multirow[t]{2}{*}{ Skin contact treatment } & \multicolumn{4}{|c|}{ Berry/plum intensity } & \multicolumn{4}{|c|}{ Overall wine quality } \\
\hline & 1999 & 2000 & 2002 & Average & 1999 & 2000 & 2002 & Average \\
\hline $10^{\circ} \mathrm{C} 1$ day & 4 & 3 & 4 & 4 & 4 & 3 & 4 & 4 \\
\hline $10^{\circ} \mathrm{C} 2$ days & 1 & 2 & 1 & 1 & 1 & 2 & 1 & 1 \\
\hline $10^{\circ} \mathrm{C} 4$ days & 2 & 1 & 2 & 2 & 3 & 1 & 2 & 2 \\
\hline $15^{\circ} \mathrm{C} 1$ day & 3 & 2 & 3 & 3 & 4 & 1 & 3 & 3 \\
\hline $15^{\circ} \mathrm{C} 2$ days & 1 & 3 & 1 & 1 & 1 & 3 & 1 & 1 \\
\hline $15^{\circ} \mathrm{C} 4$ days & 4 & 1 & 2 & 2 & 2 & 2 & 2 & 2 \\
\hline
\end{tabular}

1 = Highest preference, 4 = Lowest preference.

\section{CONCLUSIONS}

Low-temperature skin contact prior to fermentation has a positive effect on Pinotage wine composition and quality. Under the conditions of this investigation 4 days skin contact at $10^{\circ} \mathrm{C}$ prior to fermentation yielded the most typical and highest quality Pinotage wines. This phenomenon was more pronounced in some years. This treatment is therefore recommended. Most probably 2 days at $10^{\circ} \mathrm{C}$ would also be acceptable, depending on parameters such as grape maturity. Extended prefermentation skin contact at temperatures higher than $10^{\circ} \mathrm{C}$ should be avoided. Aroma components, such as beta-damascenone and beta-ionone, have to be investigated more extensively for future use as possible impact parameters of Pinotage wine quality.

\section{LITERATURE CITED}

Di Stefano, R., Cravero, M.C. \& Gentilini, N., 1989. Metodi per lo studio dei polifenoli dei vini. L`Enotecnico 25, 83-89.

Gao, L., Girard, B., Mazza, G. \& Reynolds, A. G., 1997. Changes in anthocyanins and color characteristics of Pinot noir wines during different vinification processes. J. Agric. Food Chem. 45, 2003-2008.

Girard, B., Kopp, T. G., Reynolds, A. G. \& Cliff, M., 1997. Influence of vinification treatments on aroma constituents and sensory descriptors of Pinot noir wines. Am. J. Enol. Vitic. 48, 198-206.

Gómez-Plaza, E., Gil-Muñoz, R., López-Roca, J.M. \& Martinez, A., 2000. Color and phenolic compounds of a young red wine. Influence of wine-making techniques, storage temperature, and length of storage time. J. Agric. Food Chem. 48 736-741. 
Heatherbell, D., Dicey, M., Goldsworthy, S. \& Vanhanen, L., 1997. Effect of prefermentation cold maceration on the composition, color and flavor of Pinot noir wine. In: Henick-Kling, T., Wolf, T. E. \& Harkness, E. M. (eds). Proc. 4th Int. Symp. Cool Climate Vitic. \& Enol., 16-20 July 1996, Rochester, USA. pp. VI 10-17.

Marais, J., 1986. A reproducible capillary gas chromatographic technique for the determination of specific terpenes in grape juice and wine. S. Afr.J. Enol. Vitic. 7, 21-25.

Marais, J. \& Malan, J., 1999. Effek van gistingstemperatuur op Pinotage wynsamestelling en kwaliteit. Wynboer Tegnies 120, 11-12.

Mayén, M., Mérida, J. \& Medina, M., 1995. Flavonoid and non-flavonoidcompounds during fermentation and post-fermentation standing of musts from Cabernet Sauvignon and Tempranillo grapes. Am. J. Enol. Vitic. 46, 255-261.

Mazza, G., Fukumoto, L., Delaquis, P., Girard, B. \& Ewert, B., 1999. Anthocyanins, phenolics, and color of Cabernet franc, Merlot, and Pinot noir wines from British Columbia. J. Agric. Food Chem. 47, 4009 - 4017.

McMahon, H. M., Zoecklein, B. W. \& Jasinski, Y. W., 1999. The effects of prefermentation maceration temperature and percent alcohol $(\mathrm{v} / \mathrm{v})$ at press on the concentration of Cabernet Sauvignon grape glycosides and glycoside fractions. Am. J. Enol. Vitic. 50, 385-390

Nicolini, G. \& Valenti, L., 2001. Indagine sul corredo polifenolico di vini Sagrantino con metodiche applicabili ai controllidi processo. Riv. Vitic. Enol. 54, 49-65.
Reynolds, A., Cliff, M., Girard, B. \& Kopp, T. G., 2001. Influence of fermentation temperature on composition and sensory properties of Semillon and Shiraz wines. Am. J. Enol. Vitic. 52, 235-240.

Sefton, M. A., 1998. Hydrolytically-released volatile secondary metabolites from a juice sample of Vitis viniferagrape cvs Merlot and Cabernet Sauvignon. Aust. J. Grape \& Wine Res. 4, 30-38.

Snedecor, G.W. \& Cochran, W.G., 1980. Statistical methods. 7th Edition. The IOWA State University press. pp. 253-254.

TTimberlake, C. F. \& Bridle, P., 1976. Interactions between anthocyanins, phenolic compounds, and acetaldehyde and their significance in red wines. Am. J. Enol. Vitic. 27, 97-105.

Van Wyk, C.J., Augustyn, O.P.H., De Wet, P. \& Joubert, W.A., 1979 Isoamylacetate - A key fermentation volatile of wines of Vitis vinifera $\mathrm{cv}$ Pinotage. Am. J. Enol. Vitic. 30, 167-173.

Waldner, M. \& Marais, J., 2002. Impact aroma components in South African red wines: A preliminary study. Wynboer $161,85-87$.

Watson, B., Price, S. F. \& Valladao, M., 1995. Effect of fermentation practices on the anthocyanin and phenol composition of Pinot noir. Am. J. Enol. Vitic. 46, 404 Abstract. 46th Annual Meeting Am. Soc. Enol. Vitic., Portland, Oregon, June 1995. 